Agricultural and Resource Economics: International Scientific E-Journal

http://are-journal.com

JEL: F22, E24, O15, Q01

Mariana Bil ${ }^{1}$, Marta Barna ${ }^{2}$, Anna Zbarska ${ }^{3}$

${ }^{1}$ SI «Institute of Regional Research named after M. I. Dolishniy of the NAS of Ukraine»

${ }^{2}$ Lviv University of Trade and Economics

${ }^{3}$ National University of Life and Environmental Sciences of Ukraine

Ukraine

\title{
MIGRATION AND HUMAN DEVELOPMENT IN UKRAINE: FEATURES OF INTERACTION AND PRIORITIES OF STATE REGULATION
}

Purpose. The purpose of the article is to substantiate theoretically the relationship between migration and human development in the system of achieving the Sustainable Development Goals, to reveal a modern understanding environment of the opportunities as a factor in shaping the migration potential, to formulate recommendations for the implementation of the state policy for human development under conditions of high migration activity of the population, relevant for Ukraine.

Methodology / approach. The general scientific methods (analysis, synthesis, generalization, systematization, graphic method) and special ones (statistical analysis, comparison, organizational and managerial modeling) were the basis of the methodological approach. Current ideas in determining the competitive conditions of environment of opportunities for human development were systematized in order to generalize the theoretical foundations of the study. Statistical analysis was performed on the example of Ukraine as a migration-active country using data from international statistical platforms UNDP, IOM, ILO, Eurostat, Worldometer. Interstate comparative analysis made it possible to substantiate the need for the formation and implementation of the state policy for human development under conditions of high migration activity of the population. Ishikawa diagram specifying the target areas and the measures algorithm of their achievement was used to determine the catalyze priorities of such a policy.

Results. In the article there were made the theoretical and applied justifications for the modern understanding of migration, human development and their interaction in terms of the formation of the internal environment of opportunities in the global mobile space of competitive redistribution of human potential. The interstate comparative analysis of the main socio-economic indicators on the example of Ukraine to identify applied problems of human development of a migration-active society was conducted. The excessive gaps indicated the priority spheres of state policy for human development as a measures' set of demographic, valeological, educational, economic, environmental and security nature, aimed at ensuring decent, socially just and active living conditions with respect for choice and movement freedom. The priorities of the state policy for human development under the conditions of high migration activity of the population were offered. They provide an opportunity to substantiate management focuses on the implementation of monitoring of human development and migration, improving the efficiency of migration capital and the welfare of the population, stimulating demographic reproduction, the formation of social unity and legal culture.

Originality / scientific novelty. There were improved the theoretical and applied bases of research of relationship between human development and population migration in the context of realization of choice right and movement freedom. The methodical bases of the comparative analysis of the internal opportunities' environment of human development of migration-active 


\section{Agricultural and Resource Economics: International Scientific E-Journal http://are-journal.com}

society were further developed. The method of Ishikawa diagram (Constructing a Fishbone) to specify the priorities of the state policy for human development under the conditions of high migration activity of the population was used for the first time.

Practical value / implications. The content, purpose, spheres and priorities of the state policy for human development under the conditions of high migration activity of the population were substantiated. The applied recommendations for the implementation of such a policy for migrationactive Ukrainian society were formulated.

Key words: migration, migration activity, human development, sustainable development, state human development policy, opportunities environment, monitoring.

Introduction and review of literature. The modern world is developing in conditions of high migration activity of the population. The emergence of a global mobile space, despite the challenges of the COVID-19, remains a major trend of progressive change. The most developed countries declare the priority of forming an opportunities environment for human life with the expansion of choices. This ideology is reflected in the concept of «human development», which is a key social indicator of economic growth in theoretical and applied aspects.

Migration provides opportunities to exercise the choose right and movement freedom in the modern sense. The Universal Declaration of Human Rights UN in 1948 regulated the right to freedom movement, which consists of three main elements - movement freedom within the country, the return right to one's own country, the right to leave one's country. In addition to movement freedom, the Declaration defines the rights to seek asylum, citizenship, a decent living standard, work and education [1].

The movement freedom of certain migration regimes was regulated, human rights to protection, freedom of choice and equality were strengthened since the 1950s with the adoption of the Convention for the Protection of Human Rights and Fundamental Freedoms of the Council of Europe and the introduction of a number of amendments to this document [2].

The fundamental rights, founded more than half a century ago, define the public policy concept of developed countries, aimed at creating a favorable internal opportunities environment in which the person himself, responsible for his choices, exercises rights and freedoms and chooses a place of residence, study and work.

Migration scientists claim that the world is becoming less migratory but more mobile [3]. The perception and regulation of migration has also undergone a long evolution in the formation of conceptual foundations and applied approaches in the application of management tools. The development of a «democratic society of opportunities» determines the legal dominant in the regulation of migration - the establishment of migration regime with a balance of human rights and freedoms [4]. This increases the need to use indirect tools to regulate migration at the stage of formation of its potential and the protective component at the stage of its implementation. Attempts to unify approaches to migration management led to the adoption in 2018 at the level of the UN and IOM of the Global Compact for Safe, Orderly and Regular Migration. It is expected to help make migration a benefit for all 
participants [5].

Thus, modern migration research should strengthen the legal framework for the implementation of movement freedom with the primary use of indirect regulation methods, aimed at creating an internal competitive environment of democratic society. The human development concept allows us to analyse the trends of such environment, to identify the causes and consequences of migration at different institutional and spatial levels (person, household, settlement, region, state).

The opposition of human values and interests to the goals of economic growth has led to the emergence of the human development concept as a complex theoretical and applied category for assessing various socio-economic phenomena and processes. The concept of human development began to actively form during the methodology and measurement of the Human Development Index (HDI), presented UN in 1990. In the first UNDP reports, human development is seen as a process of empowerment for human beings [6]. Today, the content of human development is concretized according to its goals - it is a process of empowering a person to live a long, healthy and creative life, as well as to solve other important tasks, to participate in ensuring justice and sustainable development [7].

The author's definitions of human development are with different accents, because it is a complex category. "Human development» is considered in Ukrainian scientists researches as: the philosophy of Human Centered Development (E. Libanova, L. Cherenko, O. Makarova [8, p. 412]); the formation of choices opportunities and realization of human potential, which are constantly expanding (L. Beztelesna [9, p. 40]); the choices increase of the opportunities space (G. Gerasymenko [10]); the opportunities expansion with simultaneous improvement of human qualities (M. Makotsoba [11, p. 6]); the stable and dynamic (at the same time) equilibrium of opportunities expansion that would allow to meet the growing human needs, to realize human potential for ensuring a decent life (N. Markova [12, p. 11]).

The scientific discussions and substantiation outline the priorities of human development policy:

- implementation of the human-centric paradigm in all spheres of state policy;

- creating a favorable internal environment opportunities and realization of the economy socialization potential while respecting the rights and freedoms of choice and movement (S. Sardak, O. Bilska, A. Simakhova [13, p. 7]);

- promoting the realization of human potential, its development and quality improvement, including the accumulation of human and social capital;

- creating new opportunities for the human potential use - spheres of employment, business, social and political activity, taking into account global competitive trends;

- ensuring the transformation of the results of the human potential use into decent parameters of life, as evidenced by external and internal assessments.

The broad issues of human development determine the numerous spheres of economic research, which often become interdisciplinary. Research into human 
development is actively developing the issue of its relationship with environmental and economic processes (J.-E. de Neve, J. Sachs [14]), socio-demographic and cultural-value transformations (P. Greenfield [15]), introduction of social innovations (J. Howaldt [16]), ensuring inclusive human development (J. Nwachukwu, S. Asongu [17]).

The scenarios of human development for the near future in the publications of the world's leading scientists are substantiated. In particular, in collective work of D. P. van Vuuren, K. Riahi, K. Calvin, R. Dellink etc were identified 5 areas for assessing human development, based on indicators of population, urbanization, income, energy consumption and production, agricultural production and land use, as well as emissions and climate change [18]. Actually, these areas outline the basic issues of human development research in various spheres of its provision.

Consideration of human development processes is closely related to the study of human potential and human capital. Human potential reveals the personal characteristics (physiological, psychological, intellectual, educational, qualificational, organizational), the use of which (depending on the environment of opportunities) can provide a decent life, expressed in well-being and happiness [19]. The modern understanding of human potential reinforces the hedonistic and eudemonic aspects of interdisciplinary behavioral economics in conjunction with the human development concept.

Human capital is an economic category that reveals the efficiency of human resources with a reflection on the population welfare and economic growth indicators. One of the human capital characteristics the last period, at least in the most developed countries, is its rapid accumulation, which actualizes the study of its relationship with economic processes. According to scientists J. Čadil, L. Petkovová and D. Blatná human capital should correspond to the economic structure, stimulating economic growth; otherwise the unemployment rate will remain high, even if human capital develops as the level of education of the population increases [20].

Thus, human development in its progressive characteristics should be correlated with economic processes, stimulate them and not cause structural «dissonances». The same applies to changes in other parameters of human life - the environment state, socio-demographic and cultural processes, technological development. Human development is a complex category that allows to identify the preconditions for further progressive changes (economic, social, environmental) with the dominance of the human-centric paradigm.

The formation of human development policy is an urgent task for all countries, especially for Ukraine, which is in the conditions of long transformational changes and is involved in the neo-liberal economic mobility regime of the European Union [21]. Public policy can be implemented in a specific area or be comprehensive, setting higher goals. As a rule, experts distinguish such a policy of sustainable development. We focus on human development policy that takes into account the specifics of a migration-active society.

The expediency of focusing on human development policy in conditions of high 
migration activity of the population is due to the fact that migration for modern person expands the environment of choice. It is important for a migration-active society to implement such human development policy, which includes a set of measures of demographic, valeological, educational, economic, environmental and security nature, aimed at ensuring decent, socially just and active living conditions with choice and movement freedom.

The purpose of the article. The purpose of the article is to substantiate theoretically the relationship between migration and human development in the system of achieving the Sustainable Development Goals, to reveal a modern understanding environment of the opportunities as a factor in shaping the migration potential, to formulate recommendations for the implementation of the state policy for human development under conditions of high migration activity of the population, relevant for Ukraine.

Results and discussion. Ukraine is one of the difficult transformational countries. The several revolutions (2005, 2014), current threats to territorial integrity, many internal political and macroeconomic problems characterize the 30 -year period of Ukrainian independence.

Ukraine is the migration-active countries. This confirms its migration profile on the global mobile world map. According to IOM, Ukraine is in the top 10 countries in the world as the largest human potential donors, occupying the 8th position in 2019. However, Ukraine comes out on top by indicator «share of international migrants in population» $(11.4 \%)$ (Table 1$)$.

Table 1

Rating positions of Ukraine as a donor of migrants, million people

\begin{tabular}{|c|c|c|}
\hline 2000 & 2017 & 2019 \\
\hline 1. Russian Federation - 10.7 & 1. India -16.6 & 1. India -17.8 \\
\hline 2. Mexico -9.6 & 2. Mexico -13.0 & 2. Mexico -11.2 \\
\hline 3. India - 8.0 & 3. Russian Federation - 10.6 & 3. China -10.5 \\
\hline 4. China - 5.8 & 4. China -10.0 & 4. Russian Federation - 10.8 \\
\hline 5. Ukraine - 5.6 & 5. Bangladesh -7.5 & 5. Syria -8.5 \\
\hline 6. Bangladesh -5.4 & 6. Syria -6.9 & 6. Bangladesh -7.4 \\
\hline 7. Afghanistan -4.5 & 7. Pakistan -6.0 & 7. Pakistan - 6.3 \\
\hline 8. Great Britain - 3.9 & 8. Ukraine - 5.9 & 8. Ukraine - 6.1 \\
\hline 9. Kazakhstan - 3.6 & 9. Philippines - 5.7 & 9. Philippines - 6.1 \\
\hline 10. Pakistan - 3.4 & 10. Great Britain - 4.9 & 10. Afghanistan -5.9 \\
\hline
\end{tabular}

Source: formed by the authors on the basis of data [22; 23].

High migration activity of Ukrainian population forms the migration dependence of its economy. The foreign remittances in 2019 amounted is $7.7 \%$ of GDP [24]. Migration capital is a powerful investor in Ukraine's economy, which, however, is accompanied by a number of risks while maintaining human potential high losses. These risks are a threat to sustainable development in the long run, because in addition to the deepening demographic crisis, force majeure, such as Covid-19, will limit financial flows and cause economic «collapse» in conditions of uncertainty. 


\section{Agricultural and Resource Economics: International Scientific E-Journal}

http://are-journal.com

The migration intellectualization of Ukrainian population is one of the negative trends. In this regard, many developed countries implement policy of «high skilled migrants» attracting [25]. The intellectual migration growth, usually long-term or lifelong, determines the demographic, intellectual, labor, social threats to the further development of Ukrainian society [26, p. 152]. Ukrainian youth is characterized by high migration activity. The number of Ukrainian full-time students abroad has increased 4 times over the last decade. According to sociological survey in EU-border Ukrainian regions, $38.0 \%$ of graduates of schools, vocational and higher education institutions plan to migrate for employment or study abroad, including $5.0 \%$ - for permanent residence [27].

The high youth migration potential is a risk for transformational countries, while the young influx provides financial stability through the innovation diffusion and the provision of conditions for personal and professional development for recipient countries [28]. Migration is usually in the youth phase of the life course, so its consequences have long-term destructive character at excessive volumes [29, p. 126].

Although the migration activity of the Ukrainian population is high, the migration policy still remains unformed, especially in terms of the use of regulation indirect methods, as well as the implementation of comprehensive monitoring of migration. Since there are legal grounds for the exercise of movement freedom in Ukraine, it is extremely necessary for the country to form and implement a human development state policy in conditions of high migration activity of the population.

It is necessary to understand its main tendencies to substantiate the theoretical and applied principles of human development policy formation in Ukraine. This allows us to analyse Ukraine's rating positions according to UNDP. One of the important factors influencing population migration for migration-active societies is the formation of a global competitive space for human potential redistribution. The analysis of rating trends according to the Human Development Index (HDI) determines the country's ability to preserve human potential through the creation of a favorable internal environment of opportunities

Fig. 1 shows the dynamics of HDI for Ukraine as a whole and its main indicators - life expectancy at birth and GNI per capita. Since 2010, there has been a positive trend in HDI, but it is very slow. As for Ukraine's rating, it fluctuates constantly. This indicates the instability of the internal opportunities environment of human development, frequent competitive losing positions compared to other countries, including Europe's neighbouring countries.

If analysed in terms of HDI indicators, Ukraine's membership in the group of «high human development countries» is provided by higher educational component indicators. At the same time, the comparison of life expectancy at birth with other groups of countries indicates the worst quality parameters of the living environment of Ukrainian society. Life expectancy reveals the environment quality, the environment state, health and social protection, the level of well-being and consumption quality, the healthy lifestyle culture. Lower life expectancy means that the internal opportunities environment is not conducive to human development and 

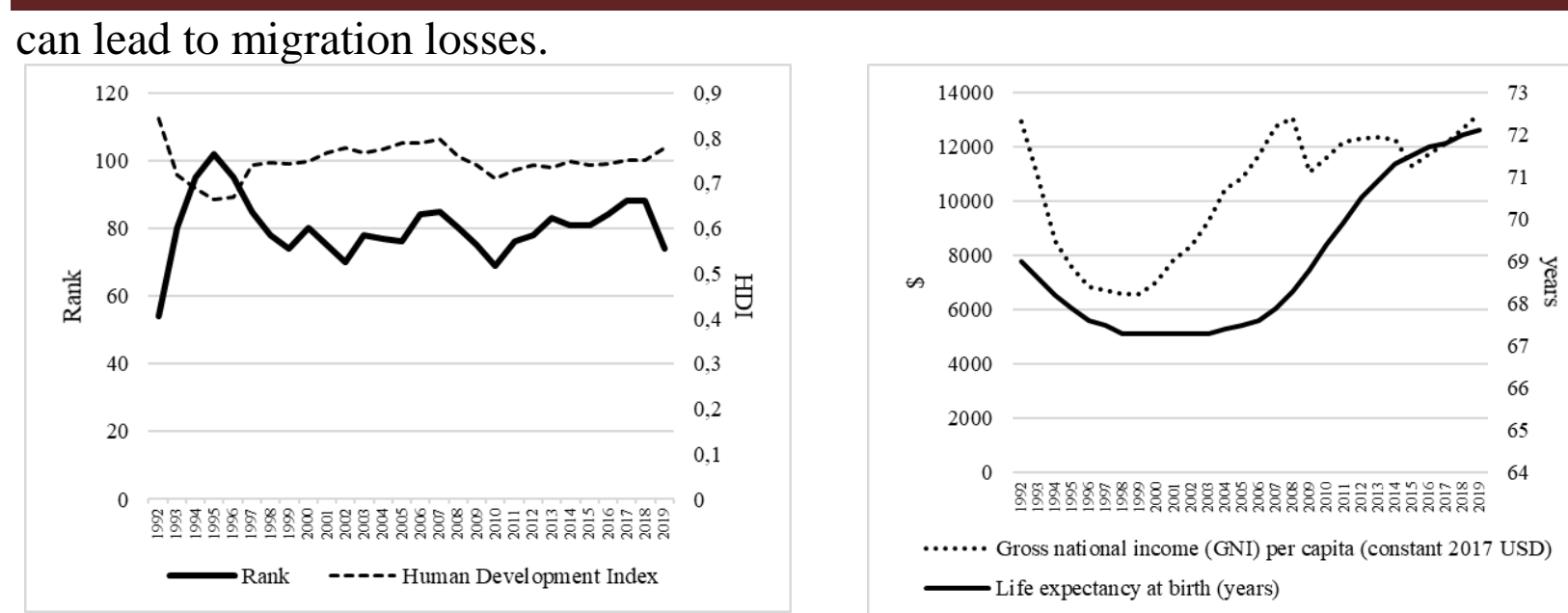

Fig. 1. Dynamics of HDI of Ukraine and its main indicators, 1992-2019

Source: built by the authors on the basis of data [30].

Ukraine in terms of life expectancy is significantly inferior to countries with high and very high levels of human development. This indicates the urgency of strengthening measures to improve the quality of the internal opportunities environment for valeological, demographic and environmental safety components.

Satisfactory comparative characteristics of Ukraine with developed countries in terms of GNI per capita are indicative, although since 2015 there has been some positive dynamics. In 2019 the gaps in Ukraine's GNI with the countries of the group «high human development» are 1039 USD, with «very high human development» 31350 USD, European and Central Asian countries - 4723 USD, OECD countries 31751 USD.

Table 2

\section{Indicators of HDI of Ukraine and different groups of countries, 2015 and 2019}

\begin{tabular}{|c|c|c|c|c|c|c|c|c|c|c|c|c|c|c|c|c|}
\hline \multirow[t]{2}{*}{ Indexes } & \multicolumn{2}{|c|}{ Ukraine } & \multicolumn{2}{|c|}{$\begin{array}{l}\text { High human } \\
\text { development }\end{array}$} & \multicolumn{2}{|c|}{$\begin{array}{c}\text { Very high } \\
\text { human } \\
\text { developmen }\end{array}$} & \multicolumn{2}{|c|}{$\begin{array}{c}\text { Medium } \\
\text { human } \\
\text { tevelopment }\end{array}$} & \multicolumn{2}{|c|}{$\begin{array}{l}\text { Low human } \\
\text { development }\end{array}$} & \multicolumn{2}{|c|}{$\begin{array}{l}\text { Europe and } \\
\text { Central Asia }\end{array}$} & \multicolumn{2}{|c|}{ OECD } & \multicolumn{2}{|c|}{ World } \\
\hline & 2015 & 2019 & 2015 & 2019 & 2015 & 2019 & 2015 & 2019 & 2015 & 2019 & 2015 & 2019 & 2015 & 2019 & 2015 & 2019 \\
\hline $\begin{array}{l}\text { Life expectancy at } \\
\text { birth (years) }\end{array}$ & 71.1 & 72.1 & 75.5 & 75.3 & 79.4 & 79.6 & 68.6 & 69.3 & 59.3 & 61.4 & 72.6 & 74.4 & 80.3 & 80.4 & 71.6 & 72.8 \\
\hline $\begin{array}{l}\text { Expected years of } \\
\text { schooling (years) }\end{array}$ & 15.3 & 15.1 & 13.8 & 14 & 16.4 & 16.3 & 11.5 & 11.5 & 9.3 & 9.4 & 13.9 & 14.7 & 15.9 & 16.3 & 12.3 & 12.7 \\
\hline $\begin{array}{l}\text { Mean years of } \\
\text { schooling (years) }\end{array}$ & 11.3 & 11.4 & 8.1 & 8.4 & 12.2 & 12.2 & 6.6 & 6.3 & 4.6 & 4.9 & 10.3 & 10.4 & 11.9 & 12 & 8.3 & 8.5 \\
\hline $\begin{array}{l}\text { Gross national } \\
\text { income (GNI) per } \\
\text { capita (constant } \\
2011 \text { i } 2017 \text { USD) }\end{array}$ & 7361 & 13216 & 13844 & 14255 & 39605 & 44566 & 6281 & 6153 & 2649 & 2745 & 12862 & 17939 & 37916 & 44967 & 14447 & 16734 \\
\hline $\begin{array}{l}\text { Human Develop- } \\
\text { ment Index (HDI) }\end{array}$ & 0.743 & 0.779 & 0.746 & 0.753 & 0.892 & 0.898 & 0.631 & 0.631 & 0.497 & 0.513 & 0.756 & 0.791 & 0.887 & 0.900 & 0.717 & 0.737 \\
\hline
\end{tabular}

Source: formed by the authors on the basis of data [31; 32].

Such gaps point to the risks of significant migration losses for Ukraine, which is part of a highly competitive European mobile space with still losing ground. This confirms the comparison of the main socio-economic indicators of Ukraine with Europe's neighbouring countries that are active migration recipients, especially Poland. From fig. 2, Ukraine lags far behind its neighbors in terms of economic 
development. Ukraine's gap in terms of GDP per capita with Poland is more than 10000 euros. Also, Ukraine has slower GDP growth than neighbouring countries, except for Slovakia.

Ukraine's financial environment is extremely unstable, which confirms the comparison of the consumer price index. Such instability makes it impossible to plan the income and expenditure of the population, its savings, investment activity. The business is in conditions of constant currency risks. Therefore, macroeconomic stabilization should be one of the conditions of human development in its economic component.

As the higher potential of migration is characteristic of young people, it is important to compare unemployment rates among 15-24 year-olds. Official statistics show that youth unemployment in Ukraine is higher than in Poland and Hungary. As for the general unemployment rate, it also significantly outperforms neighbouring countries (Slovakia's experience in reducing unemployment should be relevant for Ukraine). The opportunities environment for the realization of intellectual and labor potential in Ukraine remains satisfactory and is concentrated in large cities.

Territorial differentiation of labor market conditions is complemented by significant gaps in the wages level: if in Ukraine in 2019 the minimum wage was 142.1 USD and the monthly average - 406.1 monthly average, then in neighbouring Poland - 586.0 and 1106.8 USD respectively, Slovakia - 582.1 and 1350.2 USD, Hungary - 512.6 and 1197.4 USD, Romania - 490.8 and 1116.7 USD. Significant gaps in the wages level are a basic factor in the migration of the Ukrainian population, which is ready to incur non-economic losses of human potential to improve welfare.

The dominant influence of certain factors on the migration of Ukrainian population is confirmed by the results of regression analysis. Thus, 15 main factors were analyzed for 2005-2019 that may affect the migration of the population of Ukraine:

$$
Y=0,52 \times 1+0,88 \times 2+0,69 \times 3+1,03 \times 4,
$$

where $\mathrm{Y}$ - emigrants' number per 100000 population, persons;

x1 - workload per workplace, persons;

x2 - population with incomes below subsistence level, \%;

$\mathrm{x} 3$ - minimum wage, USD;

$\mathrm{x} 4$ - inflation index, \%.

The coefficient of determination of the equation: $R^{2}=0.85$, the multiple correlation coefficient: $\mathrm{R}=0.92$.

Testing the regression model for adequacy (according to Fisher's test) confirms that economic conclusions can be drawn based on this model. Economic factors remain dominant among the causes of migration.

The analysis confirms that Ukraine, while maintaining the existing competitive characteristics of the opportunities internal environment, risks remaining a donor of human potential in the European mobile space. The main risks arise in relation to the youth migration losses. It is important for Ukraine to stimulate human capital 


\section{Agricultural and Resource Economics: International Scientific E-Journal http://are-journal.com}

development with a systematic combination of measures for demographic security, modernization of health care, improving the quality of education, ensuring a competitive labor market and cultural progress to overcome excessive gaps in key socio-economic indicators, special attention to the issues of youth policy [36, p. 57].

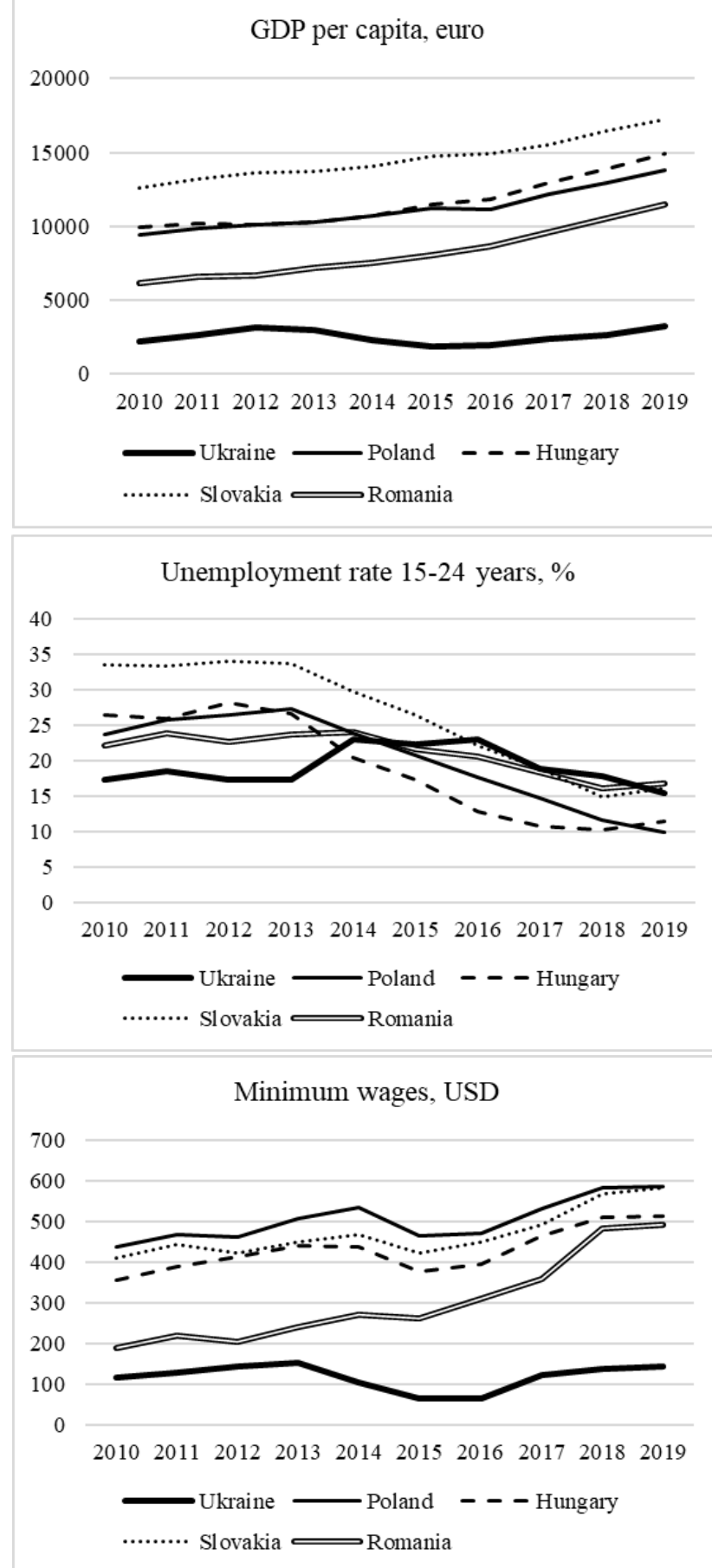

Consumer price index up to next year, \%

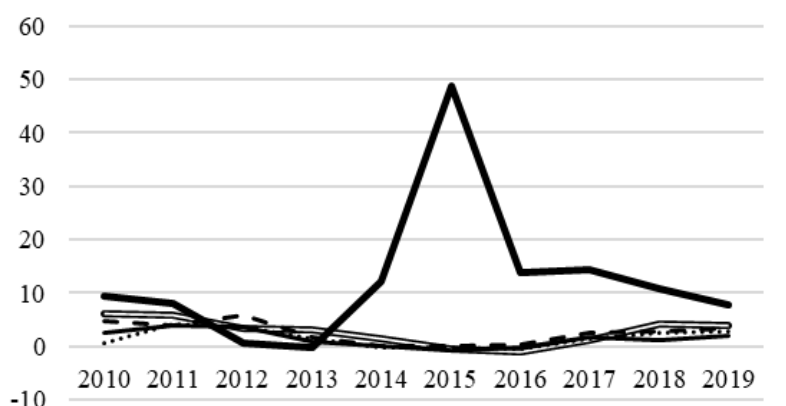

$-10$

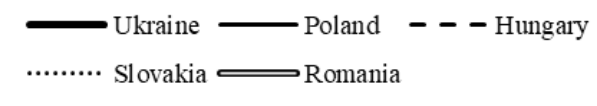

Unemployment rate $15-74$ years, \%

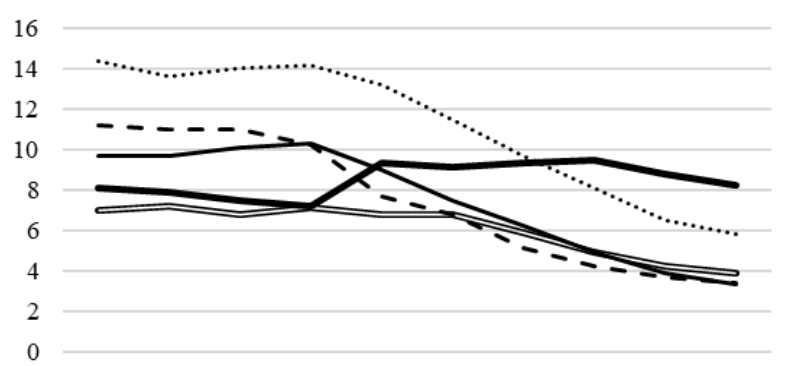

2010201120122013201420152016201720182019

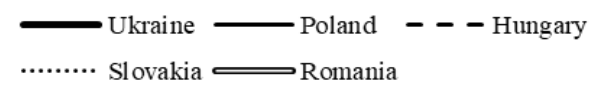

Average monthly wages, USD

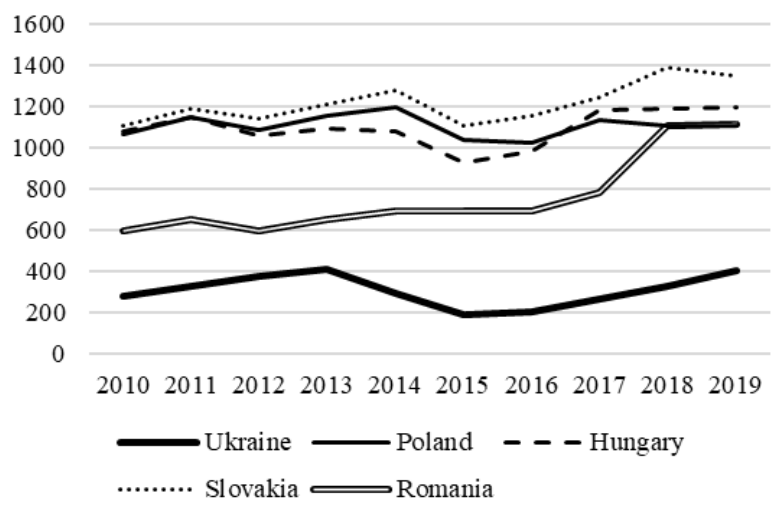

Fig. 2. Socio-economic environment of Ukraine and Europe's neighbouring countries, 2010-2019

Source: built by the authors on the basis of data [33-35].

It is extremely necessary for Ukraine to substantiate the goal, directions and tasks of the human development state policy in the conditions of high migration activity of the population. Given the content and indicators of human development 
assessment, policy in this area should be aimed at implementing measures of demographic, valeological, educational, economic, environmental and safety nature, aimed at ensuring a decent, socially just and active life with respect for the choose right and movement freedom.

The goal of the human development state policy in the conditions of high migration activity of the population should be continuous improvement of the internal opportunities environment with ensuring its competitiveness in the global mobile space of human potential redistribution.

The human development state policy should be implemented in the system of achieving the Sustainable Development Goals (Table 3).

Certain spheres of implementation of human development policy indicate its complexity with the specifics of the tools use in conditions of high migration activity of the population:

- demographic sphere - support for the development of the family institution (necessary in the conditions of distant families), regulation of demographic reproduction depending on the situation;

- employment sphere - providing conditions of decent work, transparent competitive environment of career advancement, development, remuneration, support of self-employment, innovative work, combination of different types of employment (primary, secondary, public), youth employment support package with targeted stimulation of entrepreneurship and self-employment (first job guarantees, microproject competitions, grant support etc.);

- income sphere - stabilization of the financial macroeconomic situation, promotion of efficient use of savings, support of productive employment and entrepreneurship with maximization of income;

- sphere of social protection - determination of legal conditions of double pension provision and social insurance, social protection of migrants and their family members, protection of educational migrants while maintaining social ties;

- education sphere - ensuring the quality of educational services and accessibility of educational facilities, support for different types of lifelong learning, stimulating the young re-emigration after studying abroad;

- healthcare sphere - ensuring the quality of health services, accessibility to them, promoting a healthy lifestyle and health values among youth;

- gender sphere - creating equal conditions for the realization of opportunities;

- culture sphere - support of social unity through the formation of common behavioral, event and mental values;

- sphere of civil society development - formation of principles of public administration, support of institutions of self-organization of the population and business.

The implementation of comprehensive human development state policy requires proper management experience, high political culture and appropriate resources. For the Ukrainian realities it is necessary to determine the priorities of human development state policy in the conditions of high migration activity of the 
population. It is expedient to divide them according to the goals - informational (improvement of statistical support and monitoring as a basis for substantiation of management decisions), to stimulate demographic reproduction and increase the population welfare, the formation of social unity and legal culture. Successful achievement of the set goals will allow to further «deepen» the implementation of human development policy, based on the migration situation, national and regional priorities of socio-economic development (Fig. 3).

Table 3

Spheres of implementation of human development policy in the system of achieving the Sustainable Development Goals and migration regulation

\begin{tabular}{|c|c|c|}
\hline Reasons for migration & Sustainable Development Goals & $\begin{array}{c}\text { Spheres of implementation } \\
\text { of human development } \\
\text { policy }\end{array}$ \\
\hline $\begin{array}{c}\text { Search for opportunities to } \\
\text { increase income }\end{array}$ & Overcoming poverty & $\begin{array}{c}\text { Income } \\
\text { Employment } \\
\text { Social protection }\end{array}$ \\
\hline $\begin{array}{c}\text { The need for survival, access to } \\
\text { higher living standards }\end{array}$ & $\begin{array}{c}\text { Overcoming hunger, food security, } \\
\text { food quality, sustainable agriculture } \\
\text { Social protection }\end{array}$ \\
\hline $\begin{array}{c}\text { Search for better employment } \\
\text { conditions with a decent } \\
\text { capitalization of human } \\
\text { potential }\end{array}$ & $\begin{array}{c}\text { Sustainable economic growth, } \\
\text { productive employment, decent work }\end{array}$ & $\begin{array}{c}\text { Income } \\
\text { Employment }\end{array}$ \\
\hline $\begin{array}{c}\text { Search for opportunities for } \\
\text { creative activity }\end{array}$ & $\begin{array}{c}\text { Sustainable industrialization and } \\
\text { infrastructure, innovation activity }\end{array}$ & $\begin{array}{c}\text { Income } \\
\text { Employment }\end{array}$ \\
\hline $\begin{array}{c}\text { Finding the best conditions for } \\
\text { quality of life }\end{array}$ & Healthy lifestyle, well-being & Health Care Cultures \\
\hline $\begin{array}{c}\text { Search for the best conditions } \\
\text { for the quality of education } \\
\text { and personal development }\end{array}$ & Quality of education, lifelong learning & Education \\
\hline $\begin{array}{c}\text { Avoidance of gender } \\
\text { discrimination }\end{array}$ & Gender equality & Gender \\
\hline $\begin{array}{c}\text { Avoidance of various forms of } \\
\text { harassment }\end{array}$ & Open tolerant society, legal protection & Civil society development \\
\hline $\begin{array}{c}\text { Search for better living } \\
\text { conditions and development } \\
\text { opportunities }\end{array}$ & Convergence within and between states & Income \\
\hline
\end{tabular}

Source: [37].

Main efforts should be made to regulate the young migration activity for Ukraine. Gradual migration regulation requires segmental concentration on those population groups that are most active with the emerging potential. The youth loss threatens very existence of state, so defined in Fig. 3 priorities are strategic with active demographic policy measures.

Some measures should be implemented taking into account regional specifics. This applies to the program approach to business development and self-employment, as well as encouraging re-emigration. Taking into account regional specifics in these aspects will be most useful. 


\section{Agricultural and Resource Economics: International Scientific E-Journal http://are-journal.com}

The priority of the human development state policy in Ukraine is defined as information. In particular, it is necessary to resume the assessment of the regional human development index and the publication of statistical bulletins «Regional human development», starting in 2018 [38, p. 235]. The implementation of the Methodology for assessing the opportunities environment in Ukraine with the identification of the peculiarities of the impact on migration activity and its potential is relevant. In this case, it is advisable to take into account the developments of Ukrainian authors to assess the impact on migration by groups of indicators «Demographic stability and public health status», «Education coverage», «Labour market and employment conditions», «Standard of living», «Economic development of the country» [39, p. 509].

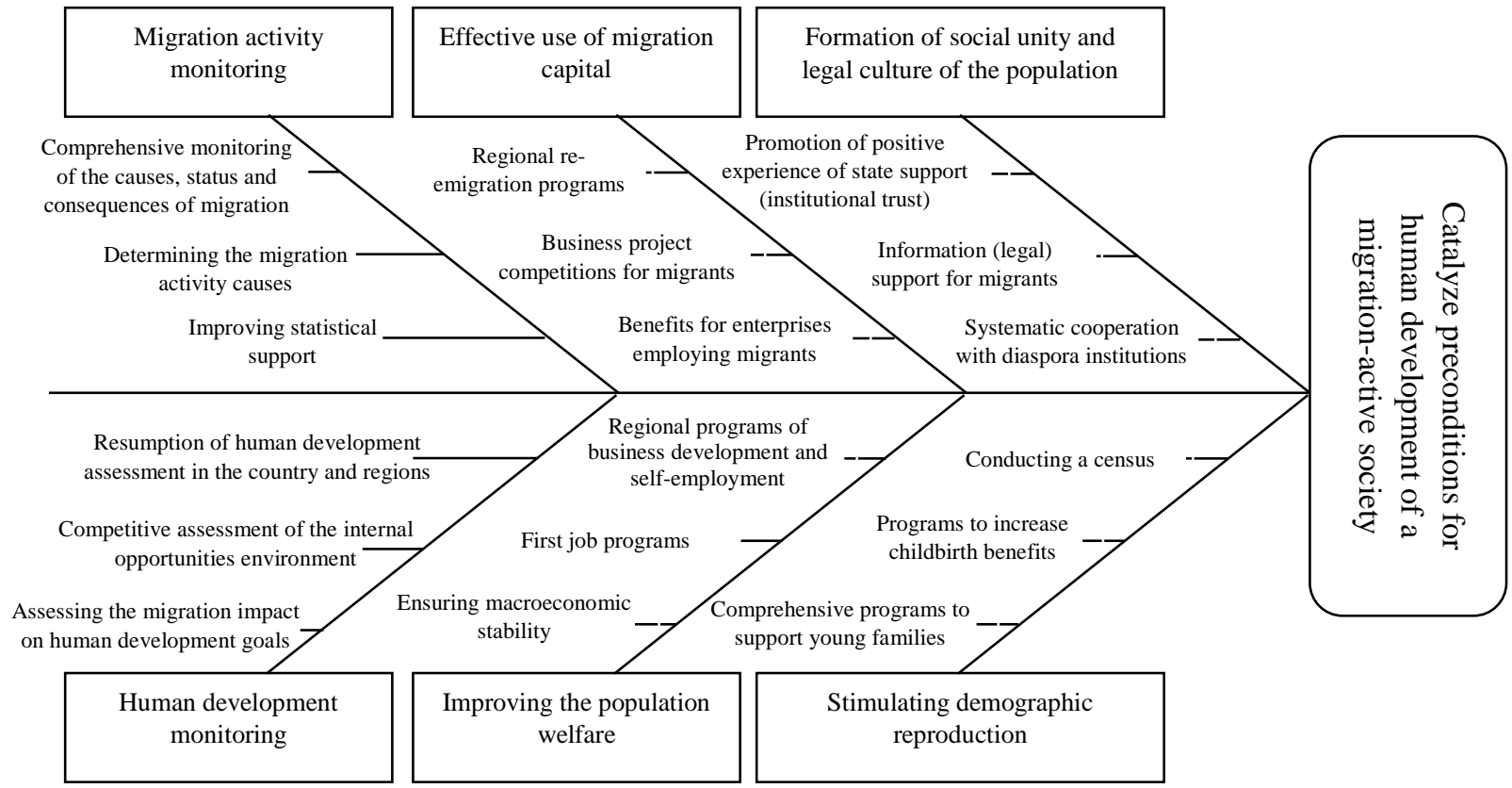

Fig. 3. Ishikawa diagram of the priorities of the human development state policy in conditions of high migration activity of Ukrainian population

Source: built by the authors.

The highest level of information support for human development and migration is the formation of a national system for human development monitoring in conditions of high migration activity of the population. In this regard, a number of measures should be taken at the initiative and coordination of specific public authorities:

- at the government level: to regulate in strategic standards the need to develop a unified approach to the formation of a information and analytical support system for the regulation of migration and human development; to initiate the development and provide resources for the work of the national monitoring system; to identify priority measures to improve the internal environment of opportunities and regulate the migration activity (potential and actual) based on the results of monitoring;

- at the level of the migration service: to organize the development of a national monitoring system with the participation of statistical services and other central public authorities that exercise powers in the economic, foreign trade, educational, 


\section{Agricultural and Resource Economics: International Scientific E-Journal http://are-journal.com}

labor, social protection spheres; to ensure the publication of monitoring data in migration profiles; to ensure the functioning of state demographic registers as an information basis for population accounting, including its movements;

- at the level of the border service: to carry out expanded collection of information when recording the crossing of the state border in order to clarify the purpose of outbound flows («diplomatic», «official», «business», «tourism», «private», «training», «religious», «cultural and sports exchange», «immigration (permanent residence)», «employment», «vehicle service personnel», «transit», «other»);

- at the level of the statistics service: to improve, if necessary, the statistical base of migration analysis concerning scenarios of movement, state border crossing, migration, labor and educational migration, social protection of migrant activists, circulating migration, migration services market, migration activity in all vectors (internal and external), causes and consequences of migration; to organize sample surveys in order to comprehensively assess the internal environment of opportunities and trends in human development; to make interstate comparisons on monitoring indicators; to publish data in the public domain;

- at the level of the employment service: to develop government recommendations on employment priorities and migration regulation; to implement measures to promote the employment of re-emigrants, providing graduates with the first job;

- at the level of education authorities: to conduct a survey of educational migration; to develop government recommendations on priorities for regulating educational migration;

- at the level of local public authorities and local governments: to ensure the collection of migration data in the regional, interregional, cross-border scales; to identify and regulate the human development priorities and regulation of migration activity; to hold competitions for micro-projects for migrants in order to attract their capital in the investment form.

The implementation of these recommendations is necessary to overcome the destructive impact of migration on human development. Migration processes should be clearly regulated and the basis for this should be systematic monitoring at all spatial management levels.

Conclusions. Thus, migration at the present stage is a way to exercise the choose right and movement freedom. It allows a person to find the best opportunities and conditions for the personal potential use and its capitalization with a reflection on the quality parameters of life. Countries in protracted transformational conditions are suffering from excessive migration losses in a globally competitive mobile space. To overcome them, it is necessary to implement the human development state policy in conditions of high migration activity of the population.

The formation and implementation of human development policy is relevant for Ukraine, which is one of the largest human potential donors in the world. Growing migration losses cause numerous risks to human development, which in the long run 
will affect the deep demographic crisis, reflected in the indicators of further development. The risks of growing migration losses are confirmed by Ukraine's competitive losing position in terms of key socio-economic indicators with Europe's neighbouring countries.

It is necessary to justify the priority measures of human development state policy of demographic, valeological, educational, economic, environmental and security nature, aimed at ensuring a decent, socially just and active life with respect for the choose right and movement freedom to improve the current situation. Given the low political culture and instability, it is important to identify those measures that will have a catalyze effect on improving the internal opportunities environment. For Ukraine, such measures include monitoring of human development and migration activity of the population, increasing the efficiency of use of migration capital and population welfare, stimulating demographic reproduction, formation of social unity and legal culture in society.

In further research, the authors will substantiate the target priorities of the human development state policy in the conditions of high migration activity of the population with the disclosure of features in different time periods.

\section{References}

1. Universal Declaration of Human Rights (1948), General Assembly resolution 217 A, Paris, the United Nations General Assembly, available at: https://www.un.org/en/about-us/universal-declaration-of-human-rights.

2. Convention for the Protection of Human Rights and Fundamental Freedoms (1950), Council of Europe, available at: https://www.echr.coe.int/documents/convention_eng.pdf.

3. Skeldon, R. (2019), A classic re-examined: Zelinsky's hypothesis of the mobility transition. Migration Studies, vol. 7, is. 3, pp. 394-403. https://doi.org/10.1093/migration/mny019.

4. Horvath, K., Amelina, A. and Peters, K. (2017), Re-thinking the politics of migration. On the uses and challenges of regime perspectives for migration research. Migration Studies, vol. 5, is. 3, pp. 301-314. https://doi.org/10.1093/migration/mnx055.

5. Global compact for safe, orderly and regular migration (2018), The United Nations, available at: https:/www.un.org/pga/72/wpcontent/uploads/sites/51/2018/07/migration.pdf.

6. Human Development Report 1990: Concept and measurement of human development UNDP (1990), available at: http://www.hdr.undp.org/en/reports/global/hdr1990.

7. Human Development Report 2011: sustainability and equity - a better future for all (2011), UNDP, New York, available at: http://hdr.undp.org/en/content/humandevelopment-report-2011.

8. Libanova, E., Cherenko, L. and Makarova, O. (2012), Liudskyi rozvytok $v$ Ukraini: transformatsiia rivnia zhyttia ta rehionalni dysproportsii [Human development in Ukraine: the transformation of living standards and regional 
disparities], Institute of Demography and Social Research, Kyiv, Ukraine.

9. Beztelesna, L. (2010), Upravlinnia liudskym rozvytkom ta yoho finansove zabezpechennia $v$ Ukraini: otsinka i perspektyvy [Management of human development and its financial support in Ukraine: assessment and prospects], NUVGP, Rivne, Ukraine.

10. Gerasymenko, G. (2017), Review of international experience of measuring human development at subnational level. Demography and social economy, vol. 1, pp. 11-23. https://doi.org/10.15407/dse2017.01.011.

11. Makotsoba, M. (2012), Progress in human development of regions of Ukraine: methodology of measurement and mechanism of maintenance, Ph.D. Thesis, Kyiv, Ukraine.

12. Markova, N. and Demyanenko, A. (2017), A Theoretical aspects of human development security. Business Inform, vol. 10, pp. 8-13.

13. De Neve, J.-E. and Sachs, J. (2020), Sustainable Development and Human Well-Being. World happiness report, Ch. 6, available at: http://happinessreport.s3.amazonaws.com/2020/WHR20_Ch6.pdf.

14. Sardak, S., Bilska, O. and Simakhova, A. (2017), Potential of economy socialisation in the context of globalisation. Economic Annals-XXI, vol. 164, is. 3-4, pp. 4-8. https://doi.org/10.21003/ea.V164-01.

15. Greenfield, P. (2018), Studying social change, culture, and human development: a theoretical framework and methodological guidelines. Developmental Review, vol. 50, part A, pp. 16-30. https://doi.org/10.1016/j.dr.2018.05.003.

16. Howaldt, J. and Schwarz, M. (2017), Social innovation and human development - how the capabilities approach and social innovation theory mutually support each other. Journal of Human Development and Capabilities, vol. 18, is. 2, pp. 163-180. https://doi.org/10.1080/19452829.2016.1251401.

17. Asongu, S. and Nwachukwu, J. (2017), Globalization and inclusive human development in Africa. Man and the Economy, vol.4, is. 1, https://doi.org/10.1515/me-2017-0001.

18. Vuuren, van D. P., Riahi, K., Calvin, K., Dellink, R. etc. (2017), The shared socio-economic pathways: trajectories for human development and global environmental change. Global Environmental Change, vol. 42, pp. 148-152. https://doi.org/10.1016/j.gloenvcha.2016.10.009.

19. Ryan, R. M. and Deci, E. L. (2001), On happiness and human potentials: a review of research on hedonic and eudaimonic well-being. Annual Review of Psychology, vol. 52, pp. 141-166. https://doi.org/10.1146/annurev.psych.52.1.141.

20. Cadil, J., Petkovová, L. and Blatná, D. (2014), Human capital, economic structure and growth. Procedia Economics and Finance, vol. 12, pp. 85-92. https://doi.org/10.1016/S2212-5671(14)00323-2.

21. Engbersen, G., Leerkes, A., Scholten, P. and Snel, E. (2017), The intra-EU mobility regime: differentiation, stratification and contradictions. Migration Studies, vol. 5, is. 3, pp. 337-355. https://doi.org/10.1093/migration/mnx044.

22. International

migration

report

2017 ,

available

at: 


\section{Agricultural and Resource Economics: International Scientific E-Journal}

http://are-journal.com

http://www.un.org/en/development/desa/population/migration/publications/migration report/docs/MigrationReport2017_Highlights.pdf.

23. International migration 2020, available at: https://www.un.org/en/file/105459/download?token=TOv3VPkm.

24. Pieńkowski, J., (2021), The impact of labour migration on the Ukrainian economy, available at: https://voxukraine.org/en/the-impact-of-labour-migration-onthe-ukrainian-economy.

25. Parsons, C. R., Rojon, S., Rose, L. and Samanani, F. (2020), High skilled migration through the lens of policy. Migration Studies, vol. 8, is. 3, pp. 279-306. https://doi.org/10.1093/migration/mny037.

26. Vasyltsiv, T., Lupak, R., Kunytska-Iliash, M., Levytska, O. and Mulska, O. (2020), Instruments of regional policy for human resources conservation by means of regulation of external youth migration of rural territories of the Carpathian region. Agricultural and Resource Economics, vol. 6, is. 3, pp. 149-170. https://doi.org/10.51599/are.2020.06.03.09.

27. Vasyltsiv, T. G. and Ryndzak, O. T. (2020), Mihratsiina aktyvnist studentskoi ta uchnivskoi molodi Karpatskoho rehionu Ukrainy (rezultaty sotsiolohichnoho opytuvannia) [Migration activity of student and pupil youth of Carpathian region in Ukraine (sociological survey results)], SI «Institute of Regional Research named after M. I. Dolishniy of the NAS of Ukraine», Lviv, Ukraine.

28. Suciu, M. C. and Florea, C. A. (2017), An empirical study on the migration among young skilled and creative people. Amfiteatru Economic, vol. 19, is. 46, pp. 727-741.

29. Huijsmans, R. (2017), Exploring the «Age Question» in Research on Young Migrants in Southeast Asia. Journal of Population and Social Studies, vol. 25, no. 2, pp. 122-134. https://doi.org/10.25133/jpssv25n2.004.

30. Human Development Data Center (2020), United Nations Development Programme. Human Development Reports, available at: http://hdr.undp.org/en/data.

31. Human Development Report 2016. The United Nations Development Programme, available at: http://hdr.undp.org/sites/default/files/2016_human_development_report.pdf.

32. Human Development Report 2020. The United Nations Development Programme, available at: http://hdr.undp.org/sites/default/files/hdr2020.pdf.

33. International Labour Organization (2020), Free and open access to labour statistics, available at: https://ilostat.ilo.org/data.

34. Eurostat (2020), Your key to European statistics. Database, available at: https://ec.europa.eu/eurostat/data/database.

35. Worldometer - real time world statistics, available at: https://www.worldometers.info.

36. Vasyltsiv, T. G., Lupak, R. L. and Kunytska-Iliash, M. V. (2019), Social Security of Ukraine and the EU: aspects of convergence and improvement of migration policy. Baltic Journal of Economic Studies, vol. 5, is. 4, pp. 50-58. https://doi.org/10.30525/2256-0742/2019-5-4-50-58. 
37. The Global Goals for Sustainable Development, available at: https://www.globalgoals.org.

38. Stolyarov, V. F. (2019), Scientific and methodological support of strategic planning and state regulation of regional human development in Ukraine. Bulletin of Economic Science of Ukraine, vol. 2, is. 37, pp. 223-237. https://doi.org/10.37405/1729-7206.2019.2(37).223-237.

39. Levytska, O., Mulska, O., Ivaniuk, U., Kunytska-Iliash, M., Vasyltsiv, T. and Lupak, R. (2020), Modelling the conditions affecting population migration activity in the Eastern European region: the case of Ukraine. TEM Journal, vol. 9, is. 2, pp. 507-514. https://doi.org/10.18421/TEM92-12.

\section{Citation:}

Стиль-ДСТУ:

Bil M., Barna M., Zbarska A. Migration and human development in Ukraine: features of interaction and priorities of state regulation. Agricultural and Resource Economics. 2021. Vol. 7. No. 3. https://doi.org/10.51599/are.2021.07.03.01.

Style - APA:

Bil, M., Barna, M. and Zbarska, A. (2021), Migration and human development in Ukraine: features of interaction and priorities of state regulation. Agricultural and Resource Economics, vol. 7, no. 3, https://doi.org/10.51599/are.2021.07.03.01. 